\title{
Research
}

\section{Paper Fish and Policy Conflict: Catch Shares and Ecosystem-Based Management in Maine's Groundfishery}

\author{
Jennifer F. Brewer $^{1}$
}

\begin{abstract}
The National Oceanic and Atmospheric Administration professes support for ecosystembased fisheries management, as mandated by Congress in the Fishery Conservation and Management Act, and as endorsed by the Obama Administration's national ocean policy. Nonetheless, driving agency policies, including catch shares and fishing quotas, focus principally on individual species, diverting attention from ecosystem considerations such as habitat, migratory patterns, trophic relationships, fishing gear, and firmlevel decision making. Environmental non-governmental organization (ENGO) agendas manifest similar inconsistencies. A case study of Maine's groundfishery demonstrates implications of this policy conflict at the local level. There, multigenerational fishing villages have historically pursued diversified and adaptive livelihood strategies, supported by local ecological knowledge. This tradition is increasingly eroded by regulatory constraints, including catch shares. Field observation, interviews, survey data, and archival review reveal that industry-supported, ecosystem-focused proposals have been rejected by the New England Fishery Management Council, despite the apparent failure of single-species approaches to sustain fish populations, fished ecosystems, and fishing-dependent communities. The creation of groundfishery catch share sectors is likely to perpetuate industry consolidation and political entrenchment under more mobile capital, following precedent set by days-at-sea, and making area protections and gear restrictions less likely. Pending marine spatial planning efforts could enhance social-ecological resilience by creating new opportunities for transdisciplinary decision support, and broader public participation and accountability.
\end{abstract}

Key Words: catch shares; ecosystem-based management; fisheries; Fishery Management Council; groundfish; ITQs; Maine; New England; NOAA; quotas

\section{INTRODUCTION}

On 19 July 2010, President Obama signed a National Ocean Policy executive order endorsing findings of the Administration's Interagency Ocean Policy Task Force, including "ecosystem-based" and "adaptive" marine resource management (Interagency Ocean Policy Task Force 2009). Meanwhile, the National Marine Fisheries Service of the National Oceanic and Atmospheric Administration (NOAA) was finalizing a national policy encouraging the use of fishery catch shares. Catch shares include limited access privileges, individual fishing quotas (ITQs), and quotas held by groups such as harvest cooperatives or fleet sectors (NOAA 2009). Both policies were informed by years of environmental non-governmental organizations (ENGOs) lobbying of NOAA and the White House Council on Environmental Quality, by Congressional mandates embedded in the Magnuson-Stevens Fishery Conservation and Management Act (FCMA)particularly its amendments in 1996 and 2006 - and by reports from bodies such as the National Academy of Sciences, U.S. Oceans Commission, and Pew Oceans Commission (National Research Council 1999, 2006, Pew Oceans Commission 2003, U.S. Commission on Ocean Policy 2004, Joint Oceans Commission Initiative 2009). Despite this breadth of input, public discussion appears not to consider the possibility that ecosystem-based management and catch shares are at odds: historically intertwined, but conceptually divergent.

Although policy conflict is nothing new, this particular divergence provides entrée to more empirically robust conversations about the future of marine resource management. Evidence from the nation's oldest commercial fishery, the New 
England groundfishery (which includes bottomdwelling species, such as cod (Gadus morhua), haddock (Melanogrammus aeglefinus), winter flounder (Pleuronectes americanus), dabs

(Hippoglossoides platessoides), grey sole (Glyptocephalus cynoglossus), pollock (Pollachius virens), whiting (Merluccius bilinearis), red hake (Urophycis chuss), and redfish (Sebastes fasciatus)) and, especially, case material from the state of Maine suggest that catch shares may deter the development of ecosystem-based management. Catch shares shift the attention of managers, fishermen, and the public away from integrated understandings of fished ecosystems and fishing practices, and toward paper fish. The term "paper fish" was coined by fishermen to refer to federal permits allowing fishing activities based on single-species stock assessments, implying that the assessments are detached from the complexities of real-world fishing practice and fished ecosystems. (The few fisherwomen in New England self-identify as "fishermen," so that term is used here.)

The National Oceanic and Atmospheric Administration now boasts 14 catch share programs in the United States. Although some fishermen have implemented catch shares with relative enthusiasm, others are deeply concerned about long-term socialecological damage. Public comments collected by NOAA in 2010 and summarized in Appendix 1 revealed a strong opposition to catch shares among both commercial and recreational fishermen, reaching $83 \%$ and $90 \%$ respectively. Maine's fishing communities have long been among the most resistant to catch shares. Opposition grows principally from socioeconomic considerations, specifically the concern that catch shares consolidate fishery access and decision making in the hands of fewer, larger, and less locally committed firms, but it also reflects concerns about ecosystem impacts. Similar objections are raised by fishermen in other locales, but often with less unanimity.

Pursuant to this argument, this paper briefly summarizes scholarship on ecosystem- and catch share-based fisheries policy in the U.S. context, presents the groundfish case study and discusses its implications, and concludes with a glance toward possible futures.

\section{Ecosystem-Based Management}

Ecosystem-oriented decision support for resource management originates at least as early as the 1930s and 1940s when biologists began advocating the protection of biodiversity and ecosystem services using politically adaptive strategies (Grumbine 1994, Scheiber 1997). Despite profound differences in conceptual and normative orientation, this history runs parallel to the evolution of fisheries yield models, which originated earlier in the 20th century, and flourished in the 1930s through 1970s (Larkin 1977). Yield models grew out of agricultural and industrial production models developed to maximize economic output-input ratios, paired with increasing biological knowledge about species population dynamics, and more-or-less nuanced conceptions of carrying capacity (Baranov 1918, Ricker 1948, Schaefer 1954, Beverton and Holt 1957).

Although principles of ecosystem management gained traction more rapidly in government agencies responsible for terrestrial resources, such as forests and wildlife, 1996 and 2006 reauthorizations of the FCMA include language intended to advance a more ecosystemic orientation in fisheries policy (McLeod and Leslie 2009). In the last decade, a veritable cottage industry of papers, reports, and special journal issues has produced proposals for more ecosystem-based fisheries management (Ecological Society of America 1998, Ecosystem Principles Advisory Panel 1999, Link 2002, United Nations Food and Agriculture Organization 2002, Pikitch et al. 2004, Browman and Stergiou 2005, Cury and Christensen 2005, McLeod et al. 2005, National Research Council 2006, Murawski 2007, Varjopuro et al. 2008, Rosenberg 2009, Tallis et al. 2010).

Central principles found in many of these frameworks include:

1. Future provision of ecosystem goods and services.

2. Adaptability and resilience to accommodate change and surprise in complex systems.

3. Interconnectedness of human and environmental variables. 
4. Broad social learning despite uncertainties.

5. Place-based understanding of cumulative impacts and cross-scalar interactions.

6. Public accountability for management tradeoffs (Ecological Society of America 1998, Ecosystem Principles Advisory Panel 1999, United Nations Food and Agriculture Organization 2002, Tallis et al. 2010).

Although some fisheries scholars and managers question the feasibility of ecosystem-based management, especially given current legal constraints and limited financial, human, and information resources, few object substantively to its core mission. Biologists employed or funded by NOAA are developing multi-species population models, and ENGOs have embraced at least the ecosystem-oriented phraseology, especially to support broader and more precautionary regulatory attention to species and habitat.

\section{Share-Based Management}

Share-based fishery management renames a policy trend pursued more or less actively in the United States since the 1980s, borrowing from Canadian experiences of the 1970s (National Research Council 1999). Finding that reductions in the issue of fishing permits were insufficient to prevent fish population declines, some economists advocated quota allocations of harvestable species to individual firms, often arguing that market transferability would create a conservation incentive because future quota values would rise with the availability of future fish populations (Christy 1973, Rettig and Ginter 1978, Copes 1979). These discussions were directly informed by older debates in economic theory between preferences for public or private stewardship of fisheries and other natural resources (Gordon 1953, Scott 1955). Advocates for individual quotas argue that the mechanism distributes fishing effort more evenly across time, thereby increasing prices and safety, reducing fleet overcapitalization, and potentially increasing conservation incentives by creating a market to internalize at least species-specific externalities (National Research Council 1999).

Much empirical evidence on catch shares is inconclusive or depicts mixed outcomes. A study of 121 individual quota fisheries and 11,014 non-quota fisheries found that individual quotas reduce or reverse rates of fishery decline (Costello et al. 2008). The study estimated fishery status by comparing historical harvest levels, however, not living fish populations or other ecosystem variables, and did not control for differences among fisheries or management mechanisms that might be implemented simultaneously with quotas. Even examining the single case of British Columbia halibut ITQs, two recent papers found evidence supporting rather different arguments. One found that market distortions around capital and information access necessary for quota leasing undermine broad distribution of public goods (Pinkerton and Edwards 2009). Another argued that ITQs nonetheless increase halibut landings and overall income (Turris 2010). Although these findings are not incongruent, they remind us that different truths become more and less salient at different scales of analysis, and that policy decisions require difficult trade-offs among competing social priorities. Given evidence of social-ecological externalities in the groundfish case, it may be that quotas are better for target fish populations and capital investors than for socialecological diversity, or collateral ecosystem goods and services.

In the U.S., ITQs were created for Atlantic surf clams and quahogs in 1990, for South Atlantic wreckfish in 1992, and for Alaska halibut and sablefish in 1995 following more protracted public debate. Shortly thereafter, the 1996 FCMA amendment encouraging ecosystem approaches to management also imposed a moratorium on ITQs and commissioned a National Academy of Sciences study, responding to concerns about privatization of public trust resources voiced by both less capitalized fishing firms and ENGOs. The Academy study underscored social and ecological concerns about ITQs, but recommended that they be permitted with provisions for detailed oversight and review (National Research Council 1999). Major national ENGOs largely opposed, expressed concern about, or were neutral on ITQs through the mid 2000s, and some lobbied for close federal oversight in FCMA 2006 reauthorization (Marine Fish Conservation Network 2007). The Environmental Defense Fund, however, has long advocated individual transferable fishing quotas with few restrictions on transferability, true to its belief in the ability of private property rights to resolve environmental problems (Environmental Defense Fund 1994). 
In 2004, the Bush Administration announced support for "dedicated access privileges," meant to encompass individual and group quotas (Office of the President 2004). Reauthorization of the FCMA in 2006 subsequently lifted the ITQ moratorium, and replaced it with industry referendum requirements only for any New England ITQ proposal. In 2008, Environmental Defense's Board Vice Chair was appointed as NOAA's top administrator, and in 2009, a Pew report expressed support for catch shares (Pew Environment Group 2009). Subsequently, the Obama Administration endorsed ITQs along with less market-driven quota systems, and devoted NOAA resources to implementation (Catch Shares Working Group 2008, National Oceanic and Atmospheric Administration 2009). By summer of 2009, when public comment was submitted on a transformative sector quota proposal in New England's groundfishery, pivotal marine ENGOs including the Ocean Conservancy, Conservation Law Foundation, Environmental Defense, and Pew Environment Group endorsed catch shares and facilitated the electronic submission of 9245 form letters from their supporters across the country. Close affiliate Oceana supported catch shares in principle, but feared that New England sectors might be held up by legal challenges because they sidestepped industry referendums. By this time, Environmental Defense had hired fishing community organizers to promote catch shares from coast to coast.

Individual transferable fishing quotas and related catch share programs have raised objections from many social scientists and small-boat fishing groups, reflecting arguments that:

1. Quota supporters overestimate conservation incentives because they overlook the significance of informal social norms, bounded rationality, and regulatory noncompliance.

2. Because quotas are usually transferable, legally or illegally, industry consolidation is virtually inevitable, so that less capitalized firms and more remote fishing harbors lose fishery access or become harvesting contractors to vertically integrated firms.

3. Quotas are usually allocated based on past fishery participation, granting windfall profits to firms with the highest landings.
4. Quotas do not sufficiently internalize habitat and cross-species externalities.

5. Conservation success of quotas requires that the total fishery-wide allowable catch limit is set appropriately.

6. Many quota programs lack transparency and public accountability, partly because advocates employ neoclassical economic theory to espouse quota shareholders' capacity for selfgovernance.

7. Quotas become capitalized, politically entrenched, and difficult to rescind, even with codified review or sunset provisions.

8. Market distortions, rent-seeking, information asymmetries, and path dependencies arise (Copes 1986, Davis 1996, Rieser 1997, National Research Council 1999, Criddle and Macinko 2000, McCay 2004, Degnbol et al. 2006, Bromley 2009, Pinkerton and Edwards 2009).

These authors cite more than two decades of accumulated evidence critiquing neoclassical economic theory through empirical studies of common property resource management institutions, especially informal social relations not codified in law (National Research Council 2002, Dolšak and Ostrom 2003, Berkes 2008, Hanna 2008, RamirezSanchez and Pinkerton 2009). A few further question the undergirding concepts of total allowable catch and maximum sustainable yield upon which catch shares are predicated, arguing that without more precautionary or ecosystemcognizant implementation, these aggregate targets can prioritize management attention to singlespecies populations and thereby discourage consideration of habitat and cross-species variables (Larkin 1977, Wilson et al. 1996, Walters et al. 2005, Finley 2009). More recently, at least one author has suggested that catch shares might discourage ecosystem stewardship (Gibbs 2009, 2010). Although this argument is not new to some long-time fishery participants and observers, it is not yet established in the scholarly literature and merits further empirical support as provided in the case study below. 


\section{METHODS}

This study uses a modified grounded theory methodology (Glaser and Strauss 1967, Strauss and Corbin 1990, Glaser 1994). Grounded theory is not social theory per se, but methodological practice, standard among social scientists relying mainly on qualitative data sets. It iterates phases of data collection and textual and discourse analysis, often producing a series of nested sampling frames, and a multi-level explanatory framework. This includes first-order analyses with the greatest internal validity, often of more prospective use to local field professionals than to theoretical interpretation, and higher-order analyses with greater external validity and conceptual relevance. Analysis is premised on constant comparison, or the trained researcher's persistent and rigorous comparison of new data with an emerging conceptual framework, including the production of extensive field notes and memos. Although less transparent than quantitative methods, this qualitative approach can answer research questions for which quantitative methods may be inadequate or impractical. Unlike public opinion polling, for example, discourse analysis allows subtle contextual cues to compensate for the reality that individuals simultaneously hold varied and inconsistent opinions, and that the relative weighting of these within a single individual's rationality and corresponding behavioral and rhetorical choices fluctuates and evolves over time (Haraway 1988, Sen 2009). In a utopian world, with unlimited public venues in which to clarify values, exchange information, and compare conflicting viewpoints, individual and collective rationalities would be easier to fix and quantify. The reality of marine resource policy, like most human arenas, is much less tidy.

The case material presented here was developed through synthesis of existing scholarship; archival review of government documents, news media, fishing industry and ENGO publications, and local histories; and common social science field data collection techniques. It synthesizes research from several smaller projects conducted between 1998 and 2010, primarily in Maine, but also in Washington, D.C., elsewhere in New England, the southeastern U.S., Alaska, and abroad. I conducted extended in-person interviews ranging from a halfhour to several hours in length, included formal and informal conversations with more than 165 fishing industry members, public servants, NGO staff, scientists, and other coastal residents and professionals. Of these, the vast majority were purposively sampled. That is, I selected them individually to represent particular groups or viewpoints. In particular, I chose fishing industry members to represent a range of business models, target species, gear types, career histories, and home harbors, as summarized in Appendix 2. I conducted shorter, informal, substantively research-related conversations with at least another 200 members of the same groups. I also collected 49 mail survey responses from three randomized samples of state license holders for commercial marine harvesting and commercial lobster fishing. These solicited information about personal fishing histories, opinions on selected management issues, and perceptions of industry participation in management. Research assistants conducted telephone interviews with a stratified random sample of 36 Maine-based federal groundfish permit holders and crew members. These focused again on personal fishing histories, especially as these were affected by groundfish management. I convened four focus groups in eastern Maine on local experiences of fishery management impacts. I undertook participant observation at more than 40 public meetings and more than 35 non-public policy briefings, conferences, and project meetings in New England, Washington, D.C., North Carolina, and Alaska; and in fishing households, on fishing vessels, on piers, and on other fishing-related premises. Some participant observation took place as dedicated scientific investigation, some during 4 years of experience as a policy and resource management professional in federal and state government and non-profit organizations.

\section{CASE STUDY RESULTS}

\section{Maine's Historically Adaptive Fleet}

Whereas virtually all fishermen consider atmospheric, oceanographic, and inter-species phenomena on annual and interannual scales, smallboat, diversified, multi-generational owneroperators often have fewer financial and technological buffers between their business plans and ecosystem change and may accumulate a richer store of ecosystem knowledge, at least on a local scale. Maine retains more firms of this type than do most U.S. states. Reviewing the historical evolution of the industry helps clarify its legacy of ecosystembased thinking. The first centuries of this history are not unlike those experienced by other fishing states 
on the eastern seaboard. In the last century, however, the easternmost state's relative distance from urban markets facilitated the continued passage of local ecological observations from one generation to the next.

Although England colonized the Maine coast in the early 1600s with the immediate intent of exporting dried codfish to Europe, when domestic markets grew in the 19th century they also diversified, first to include mackerel, halibut, haddock, pollock and hake, then soft-shelled clams, herring, lobsters, crabs, scallops, salmon, shad, alewives, smelt, striped bass, eels, sturgeon, and porgies (Vickers 1994, Lipfert et al. 1995, O’Leary 1996, Lear 1998). In the 20th century, new markets emerged for species such as flounder, whiting, redfish, tuna, shrimp, mussels, quahogs, urchins, periwinkles, dogfish, skates, and sea cucumbers. Fishing gear historically included dip nets, hand rakes, hand lines, gill nets, weirs or beach seines, fyke nets, pots and traps, stop seines, and spears. Tub trawls, or setlines, came into use in the second half of the 19th century in Maine, using longer rope coiled in tubs with many more hooks to catch groundfish, but as late as 1930, some boats were still using hand lines (Lear 1998). Small-boat diversified fishermen still use tub trawls for halibut, although in the 1970s most shifted to wire longlines, which are more stable on bottom. Net trawls of sorts were used in New England in the 19th century, and in the 1930s, some Mainers adopted the otter trawl, which is a bagshaped net kept open to catch more fish with each tow by heavy wooden or metal doors mounted along the lines between the net and boat. Although it required a more powerful boat engine, it enabled year-round groundfishing because most groundfish will not take baited hooks during summer months when they prey on migratory herring schools.

Maine's fishing fleet has long been dominated by boats smaller than $12 \mathrm{~m}$ in length, except for a few decades of capital investment and ownership concentration in the second half of the 19th century. Concentrated investment ended with the innovation of refrigerated rail cars to travel more southerly routes, market promotions by the emerging meatpacking industry, changing urban tastes, and cheap Canadian salt cod. Small Maine boats with local crews have historically ventured to grounds as distant as the Grand Banks, Gulf of St. Lawrence, and shores of Newfoundland and Labrador
(O'Leary 1996), but most have always preferred to fish close to home for reasons of comfort and safety. Few individuals in the state have ever owned more than one fishing vessel at a time, most owners captain their own boats for the majority of their career, and in the past, crew and shareholders were mainly close kin (O'Leary 1996). With future fishing access now less certain due to both population declines and regulatory constraints, kinship remains a powerful factor in industry relationships, but is supplemented with a somewhat broader array of social ties (Brewer 2010). In the last two decades, regulatory trends outlined below have favored larger, more mobile boats.

Until the late 20th century when entry limits were implemented, first in federally managed fisheries and then in state-managed fisheries, the vast majority of Maine fishermen targeted a number of marine species in seasonal livelihood strategies reliant on fishing and non-fishing incomes, barter arrangements, and subsistence (Brewer 2010). As one fisherman said in 2003, referring to his experience fishing for lobster, herring, shrimp, groundfish, and scallops, "[M]y way of fishing, for 30 years, is I've done a little of everything to survive. And if you look at Maine, that's what we did for three or four hundred years. If it wasn't herring, it was groundfish... And the further down east you go, the more they depended upon diversity to survive, not just lobstering" (field interview, 27 August 2003, Casco Bay, Maine).

Typical non-fishing activities included fishing gear construction and repair, smallholder forestry and woodcutting, hunting, building trades, woodworking, boatbuilding, gardening, handicrafts, and services for summer residents and visitors. As in many other small-boat diversified fleets, fishing pressure was flexible, varying annually and interannually with species populations, markets, weather, and local availability of labor, capital, and information (Wilson 1982, Acheson 1988, Griffith 1999, Brewer 2010). New fishery participants were limited at the local harbor level through informal social sanctions, with consideration of social-ecological factors (Acheson 1988, Wilson 1990, Brewer 2010). Today, however, the overwhelming majority of Maine's more than 6000 commercial fishermen rely primarily on lobster, partly because catch shares and fish population declines pushed them out of groundfish and other fisheries. 


\section{The Evolution of Catch Shares and Alternatives}

In the 1960s, Maine and New England witnessed large fleets of factory-scale trawlers from Europe and Asia fishing within sight of land. Congress responded in 1976 by creating the U.S. Exclusive Economic Zone, expelling foreign vessels, offering loans and savings programs for new and bigger domestic boats, and creating eight Regional Fishery Management Councils. Council members have comprised mostly fishermen and state managers, originally tasked to advise NOAA on how to build up and regulate the U.S. fleet. Various share-based regulations have been imposed since, often with mixed results, as described below and summarized in Fig. 1.

\section{Fleet Quotas}

Fleet quotas were the first experiment in groundfish catch shares, and a disastrous one. In 1977, NOAA set a preliminary total allowable catch for New England groundfish, triggering a fishing derby among firms fearing a fishery shutdown, and causing prices to collapse. Some boats landed fish in small harbors where they could avoid reporting. Others caught or falsely reported harvests from Canadian waters, which fell under a separate quota (Hennessey and Healey 2000). Attempts to allocate fleet quotas by vessel size, and by quarter year, failed to prevent derbies and non-compliance (Murawski et al. 1997, Groundfish Task Force 2004). Larger boats that previously fished offshore started fishing closer in because quotas could be achieved more rapidly with less travel time (Hennessey and Healey 2000). When fleet quotas were discontinued in the early 1980s, fishermen were already noticing nearshore groundfish depletions. As one lifelong Casco Bay fishermen said in 2003, "[W]e found that the fish were just getting farther and farther offshore. I was used to making a good living within 20 or 30 miles of the coast. But then we got off to 70 . And more nets, more nets. When I first started we had 24 nets and when I ended we had like 46" (field interview, 27 August 2003, Casco Bay, Maine).

\section{Trip Quotas}

Along with fleet quotas came trip quotas. Starting in 1977, daily and weekly trip limits were set for cod, triggering regulatory discards. Interview and participant observation data document that, in some places, at some times, experienced captains can avoid non-target groundfish species, but at other times, in other places, they find themselves with large hauls they are forbidden to land. When forced to dump already-dead fish, forbidden even from donating them to the needy, they typically respond with intial feelings of horror, outrage, disgust, and eventually helplessness and disillusionment at the failure of management to prevent ecological tragedy as well as financial loss. Expression of such sentiments by Gulf of Maine fishermen has been well documented by Council staff (New England Fishery Management Council (NEFMC) and National Marine Fisheries Service 2003). As one persistently conservation-minded Council member and fisherman argued prior to a trip limit vote, "I would say this Council better do some soul searching and better do it real quickly...[T]hrowing everything over the side solves nothing. Quite frankly I think it's a disgrace. I think we should have never done it in any stock. I've been opposed to it from day one" (field audio recording and notes, 23 June 2010, Portland, Maine, NEFMC meeting). The imposition of trip limits for cod, haddock, and other species resulted in undocumented reports of up to 8000 pounds of cod discards per boat per day, but was repeated at least six times through 2010 as the New England Council struggled to comply with NOAA's total annual catch targets (Hennessey and Healey 2000, NOAA 2001, Groundfish Task Force 2004).

\section{Gear Restrictions}

Fishing gear restrictions represent a non-catch share management alternative, one that has been used in the groundfishery, but not as much as it could be. Minimum net mesh sizes were established in 1953 and have been increased many times since (NOAA 2004). Extended field observation, interviews, and archival review show that a small but increasing number of fishermen have repeatedly proposed additional gear restrictions such as:

1. Reducing numbers of gillnets allowed per boat.

2. Increasing gillnet mesh sizes to increase survival rates of smaller fish.

3. Increasing the frequency of gillnet tending and reducing bycatch mortality. 
Fig. 1. Timeline of key national policy and regional management events in the New England groundfishery since federalization.

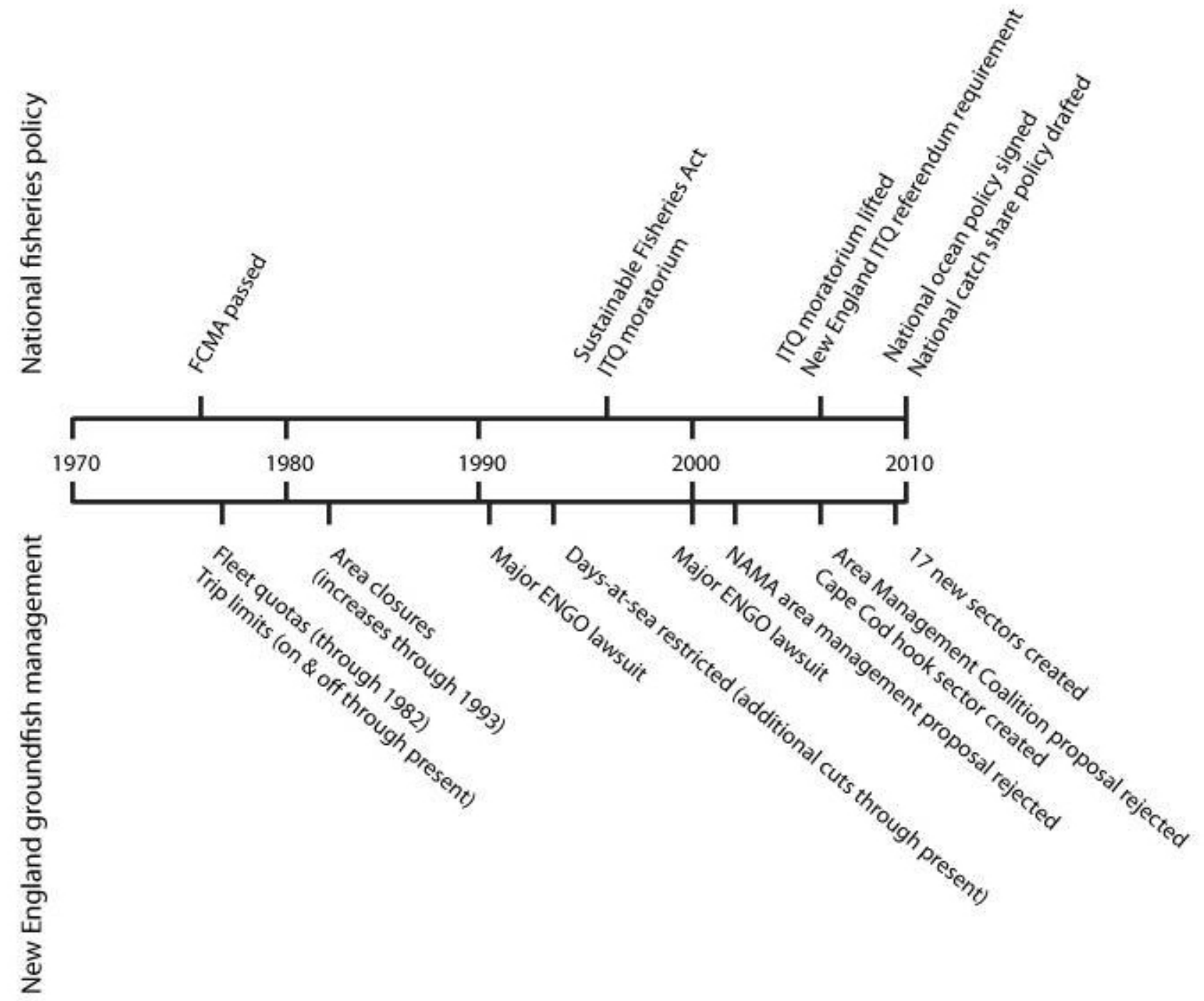

4. Increasing trawl net mesh sizes to increase survival rates of smaller fish.

5. Incentivizing hook fishing to reduce benthic impacts and low selectivity by otter trawls, and non-target species bycatch in gillnets.

6. Installing panels of trawl net mesh on the square instead of the diamond, to keep net openings larger while being dragged through the water so more fish can escape, especially round-bodied species like cod.
7. Limiting the size of rubber rollers on otter trawls, to deter dragging on rough bottom, which is preferred habitat for some groundfish species.

8. Limiting the length of otter trawl ground cables, to reduce mud clouds that induce fish to move toward the net.

9. Banning nighttime otter trawling, to prevent capture of cod when they aggregate on bottom to spawn, and to reduce gear conflicts with 
lobster traps (Northwest Atlantic Marine Alliance 2002, Area Management Coalition 2006).

In the 1980s, few fishermen were willing to support such proposals, as they were unwilling to support most management proposals in general. As the fishery has declined, however, and as NOAA has increasingly promoted catch share options, more fishermen agree that gear restrictions would be better than catch shares, for fished populations, for habitat and non-target species, and for the long-term sustainability of fishing-dependent businesses and communities. The Council rejected all but the first two of the gear restrictions above, however. In the case of roller sizes, cable length limits, and nighttime trawl bans, Council staff indicated that credit could not be granted toward the achievement of total catch targets, because of insufficient data to project corresponding effort reductions (email comm., 12 August 2010, southern Maine).

Away from public scrutiny and regulatory posturing, increasing numbers of non-otter-trawl fishermen, including some former otter trawlers, privately support proposals to restrict otter trawling, citing impacts on benthic habitat and non-target species. The vast majority of Maine fishermen fervently advocate bans on midwater trawls, which are used to harvest herring, again citing (1) bycatch of groundfish and other species because the nonselective nets use small mesh and harvest large volumes in short time periods, (2) the ability of trawls to harvest entire aggregations of densely schooled fish, whereas seines can only remove smaller and less densely schooled volumes, and (3) benthic impacts because the gear can sometimes fish on bottom. In a non-random sample of dozens of industry members over several years, the level of this industry sentiment surpassed $99 \%$, including even Maine-based midwater trawler crew (pers. comm., 2003, Damariscotta, Maine).

\section{Area Management}

Gear restrictions have long been linked to area management, both being input restrictions whereas catch shares are output restrictions. The New England Council began implementing area closures in 1982, first seasonal ones, then permanent (Murawski et al. 1997, Groundfish Task Force 2004). Many closures have eventually won industry support because they are recognized to protect nursery and spawning grounds, migration corridors, and non-target species (Northwest Atlantic Marine Alliance 2002, Area Management Coalition 2006). As a third-generation mid-coast Maine trawl boat captain wrote, "[G]roundfishing was banned in five designated areas off New England's shores...[T]here is no bottom trawling allowed in these areas, and there shouldn't be." (Libby 2010) Some fishermen assert that closures would be more effective if timed differently, if increased or decreased in size, or if opened and closed using real-time observational data, and a few have proposed additional area closures. Many fishermen, including a few otter trawlers, privately support proposals to restrict otter trawls from additional near-shore waters, especially known spawning areas. One second-generation trawl boat owner-operator admitted, "[P] rotection of [spawning area] sites is paramount to any successful recovery of our fishery in the long term" (email comm., 26 September 2005, mid-coast Maine).

The most persistent industry-originated calls for area management have been formalized by a Mainecentered network of grassroots organizations including Penobscot East Resource Center (Penobscot East), its predecessors and allies the Northwest Atlantic Marine Alliance and Stonington Fisheries Alliance, the less active Independent Fishermen Investing in Sustainable Harvesting, and the newer and highly active Midcoast Fishermen's Association (Northwest Atlantic Marine Alliance 2002, Area Management Coalition 2006). By 2009, an Area Management Coalition proposal was supported by all these organizations, collecting signatures from 25 eastern Maine fishermen and fishing community members, plus the Ocean Conservancy and Conservation Law Foundation, and two fishing community-focused NGOs. It was verbally supported by dozens more southern Maine fishermen who attended a series of coalition meetings in 2005 and 2006. Coalition organizers estimated the number of industry supporters at 200 in 2006 when the proposal was submitted to the Council (email comm., 18 August 2010, southern Maine). Another letter of support had been endorsed by 84 marine scientists in 2003 . Even though the proposal would have implemented area management only in the Gulf of Maine, where traction for the idea seemed high, the Council declined to pursue it.

Such area-focused proposals build on the local knowledge of groundfishermen who recall placespecific, near-shore, annual cod and haddock 
spawning aggregations that have been fished out (Ames 1997). Although spawning aggregations also take place offshore, many industry-recognized locales are in or near river mouths. Some of the most experienced and attentive fishermen further observe differentiated skin colorations between what they believe to be resident and migratory subpopulations. This work has informed a developing scientific consensus that cod and perhaps other groundfish species may have substock population structures more complex and place-dependent than presently accounted for in NOAA population models used to project management outcomes (Wilson et al. 1999, Ruzzante et al. 2001, Ames 2004, Brodziak et al. 2008).

\section{Days-at-Sea}

Rather than focusing on area management or gear restrictions, in the last two decades, an unusual and heavily used management tool in the New England groundfishery has been days-at-sea. This developed in the mid 1990s, following a fisherman's proposal that each boat report some number of days out of the fishery. This was intended to partially fulfill new harvest limits in the wake of a landmark 1991 lawsuit by the Conservation Law Foundation and Massachusetts Audubon Society citing NOAA's failure to prevent overfishing of cod, haddock, and yellowtail flounder. When the Council instead elected to count active fishing days instead of nonfishing days, tied fishing days to permits, and placed a moratorium on new permits, a potentially transferable property right was created. Although a day-at-sea is not a catch share per se, because it represents a fishing input not an output or quota, it does represent a discrete and individual fishing opportunity, and manifests many of the same operational features as an individual fishing quota. Individual days-at-sea were allocated and repeatedly reduced based on permit landing histories in Council-selected years, have become legally transferable across permits by lease or by permit sale, and can be aggregated from several permits onto one boat. Considerable industry consolidation has taken place as a result. There is also less transparency of permit ownership and decision making because more permit holders are now incorporated, and processors and other nonfishing interests have become more active investors.

Dozens of interviews reveal the perverse incentives created by days-at-sea. Simultaneous with days-atsea reductions to meet NOAA effort reduction requirements, firms have learned to use limited fishing time more efficiently, even at risk to human life when captains become more reluctant to end a fishing day early because of gear malfunctions, weather, or other problems. Because boats must make the maximum profit possible for every hour at sea, they broadcast their effort less widely and focus on proven grounds. This may aggravate the depletion of localized substocks below recovery thresholds, and can raise rates of non-target species discards because captains encountering non-target species are less willing to spend time steaming elsewhere. According to one second-generation groundfish and shrimp trawler, "Personally, I think that protecting small fish is a high priority. Small fish live in spawning areas. Under the current rules, days at sea, a fisherman is almost compelled to catch as many as he can regardless of size of the fish or if he is in a spawning area because that clock is ticking. There is no time to go searching for larger fish because you are losing precious time" (email comm. 26 September 2005, mid-coast Maine).

Under days-at-sea, larger otter trawlers are again tempted to fish closer to shore to minimize travel time, decimating inshore populations. Firms with several boats have been more able to influence differential cuts in days-at-sea allocations and rules for leasing of days because they are more able to afford lobbyists and travel to Council meetings whereas owner-operators are fishing. Non-owner boat captains are less likely to make operating decisions that would accommodate habitat and nontarget species considerations because their decision horizons are shorter than if they could count on fishing the same grounds in a few years or pass the business on to younger kin or neighbors. As one lifelong fisherman from southern Maine with experience both as an owner-operator and hired captain explained, captains running larger boats spend less time on deck and are rarely informed of the crew's observation of ecological evidence, such as bottom sediments or corals clinging to gear, harvested quantities of non-target predator or prey species, visible indicators of feeding or spawning behavior at the time of harvest, or even fish size, sex, weight, or apparent health (pers. comm., 2004, Washington, D.C.).

\section{Policy Failure}

From 1991 until the late 2000s, low cod populations remained a prevailing driver of groundfish regulation in the Gulf of Maine, initially coupled 
with low haddock populations. Haddock were recovering by the early 2000 s, and NOAA no longer believed overfishing to be occurring. Cod followed suit by 2008, but concern arose about flounder, especially on Georges Bank, the offshore perimeter of the Gulf of Maine (NOAA 2008).

In 1994, Maine had 587 federally permitted groundfish vessels, or $19 \%$ of the New England total of 3033 permits. By 2007, only 71 Maine boats were somewhat active in groundfishing, comprising $12 \%$ of the New England fleet of 574. By 2009, 24 permits were held in the eastern third of the state, but only five had any remaining usable days-at-sea. Because landings were insufficient to support local buyers, virtually all harvests and sales had shifted to western Maine. By contrast, further south, a single firm in New Bedford, Massachusetts held 30 active permits in 2009. Calculating an average harvest baseline from 1980s landings, and a conservative local economic multiplier, losses to eastern Maine alone have been estimated at $\$ 26$ million per year for more than two and a half decades. Even using a lower 1990s average baseline, those annual losses still reach \$15 million (Penobscot East Resource Center 2007). In 2007, with the urging of Penobscot East, Maine's legislature unanimously passed a joint resolution urging the Council to adopt alternatives to days-at-sea that "recogniz[e]... ecological differences between ocean regions and species" (123rd Maine State Legislature 2007). Extensive participant observation and interview data reveal that fishermen's keen awareness that days-at-sea are a poor effort measure, and their associated moral outrage at the socioeconomic and ecological impacts of management failure, decrease industry confidence in the good faith and expertise of NOAA, and in fishery recovery, thereby increasing non-compliance with, and public complaints about, fishery regulation overall.

\section{Sectors}

Despite New England's persistent resistance to catch shares, the failure of days-at-sea to conserve fish populations, coupled with funding from NOAA and several foundations for groups of permit holders organizing quota-holding "sectors," made the deeper entrenchment of catch shares a virtual inevitability by 2009 .

It should be noted that NOAA staff routinely demonstrate sincere dedication to public service while enduring criticism from the fishing industry,
ENGOs, elected officials, and academics. Perhaps with this in mind, as well as bio-economic arguments noted above, NOAA's catch share policy facilitates agency disengagement from fishery access allocation battles, delegating these to shareholding entities that may ultimately include not only fishing firms and parent companies, but NGOs. This move was anticipated by the creation of share-based sectors, pioneered by a group of Cape Cod hook fishermen who held days-at-sea and agreed to accept an aggregate annual quota allocation. This move garnered them political support from ENGOs, financial support from private foundations for administrative and advocacy work, and NOAA exemptions from daily trip limits, hook maximums, and area closures.

In 2010, the Council and NOAA granted additional share allocations to 17 newly self-identifying sectors. Many permit holders were forced into these organized groups of fishing firms by pending $32 \%$ cuts to non-sector days-at-sea. Share allocations were based on landings histories between 1996 and 2006, so that the most aggressive users of days-atsea control the most quota, and small boats plying depleted inshore waters will own little. Sectors are not subject to days-at-sea, are exempt from many area closures, are allowed to roll some overages to following years, and are thus far allowed to transfer shares freely, with virtually no caps on maximum share holdings. Although sectors were never favored by the vast majority of Maine firms, viable alternatives are now moot. Several sectors have already effectively distributed ITQs to their members, but Penobscot East convinced several small eastern Maine boats to partner with several from Martha's Vinyard, Massachusetts, and organize cooperative governance mechanisms whereby socioeconomic and ecological drawbacks of individual shares might be tempered by smallscale, local, hook gear allocations, and continuing efforts to achieve spawning area closures.

Despite any best intentions, sector-level decision making is less transparent than Council and NOAA processes, avoiding public notification, comment, and other provisions of the National Environmental Policy and Administrative Procedures Acts. Although full environmental impact statements, informed by public hearings, are prepared for many Council-level decisions, thus far sectors are only required to prepare environmental assessments, which are shorter and have no public hearing requirement. Other than Environmental Defense, 
which holds a Council seat, ENGOs that once regularly sent staff to New England Council meetings rarely do so now. Thus far, sectors have also circumvented the 2006 amendment to the FCMA requiring that specifics of any New England ITQ program be approved by two-thirds of fishery permit holders, a provision intended to ameliorate industry consolidation away from owner-operators. One sector has already been created with the express intention of holding quotas for lease to other sectors, and each sector risks elimination if it cannot marshal considerable organizational and financial resources to meet NOAA reporting requirements. In 2009, NOAA expended about $\$ 30$ million to support the preparation of sector operations plans and environmental assessments, but seems unlikely to support administrative, monitoring, reporting, and enforcement costs after the first year or few. Although a few conservation-oriented sectors have foundation funding, including those affiliated with Penobscot East, Midcoast Fishermen's Association, and the Cape Cod Hook Fishermen's Association, others are governed almost exclusively by financial interests. Many sectors have already defaulted to voting mechanisms determined by landings history, granting the most management power to permit holders with the largest and least resourceconserving boats.

Although there is potential for involvement by state or local governments as quota holders, it seems more likely that sector-level decision making will be increasingly vulnerable to influence from more mobile capital and a few NGOs, and less accountable to the broader public or to any ecosystem-based vision. Although Penobscot East and allies have asked repeatedly and without success for restrictions on trawl gear, its efforts have now been diverted to the securing and administration of quotas. Evidence from the Cape Cod hook fishermen and elsewhere in the northeast demonstrates that members of sectors ostensibly opposed to ITQs nonetheless position themselves favorably for any future individual quota distribution that might be implemented if more cooperative efforts fail (Pinto da Silva and Kitts 2006). Similarly, since at the least the early 1990s, Maine fishermen have observed that "what you don't use, you lose," meaning that permits not used to maximum capacity are likely to be rescinded. Evidence from Alaskan harvest cooperatives, which preceded and resemble New England sectors, shows that although transaction costs and rent-seeking may be lowered at the Council level, less transparent political maneuvering at the cooperative level, and even Congressional intervention, can narrow the range of fishery beneficiaries, and can introduce further rent-seeking around share allocations (Criddle and Macinko 2000). Incentives have also risen for other Maine fishermen to narrow their scope of ecological concern. In the past, thousands of lobster fishermen encountering groundfish that entered their traps would take larger ones home to eat, and release smaller ones with the expectation of later harvesting them or their offspring. Virtually all now spear the smaller ones as bait because they have little hope of ever owning groundfish quotas (Brewer 2010). In the words of one Council member and mid-sized trawler owner who has long opposed catch shares, countering the argument that common conservation interests shared among sector members will foster collective governance and selfenforcement around trip limits, "I can also tell you from personal experience, there's no spirit of kumbaya here whatsoever. Nobody wants to share anything. Matter of fact, they'd gut you and eviscerate you and toss you in the harbor over a hundred pounds of fish. So this whole idea of people are going to sing kumbaya and manage this as a community, I don't know where that came from." (field audio recording and notes, 23 June 2010, NEFMC meeting, Portland, Maine).

\section{Fishing in a Brave New World}

Catch shares have changed the way fishermen think about fishing and fishery management. Field data and archival review confirm that on several occasions, the Council has been told by NOAA or Council staff that their hard-fought regulatory proposals would meet total catch targets based on species population models, only to learn some months later that the regulations required revision because NOAA population estimates had been revised with new data or modeling techniques; because industry responses to regulatory or ecological changes had altered landings, bycatch, reporting, or compliance rates; or because a court decision or ENGO action had raised the level of legal risk. These experiences reinforce industry skepticism about fisheries science and management in general, but especially about the likelihood that future catch share quotas will reward any present conservation efforts. One patriarch of a multigenerational fishing family expressed a commonly held sentiment, "These guys and their fuzzy math. 
They have these impossible equations that we'll never possibly reach. They are about control, not conservation" (field interview, summer 2001, Port Clyde, Maine).

Fishermen have learned that, under a catch share system, individual species landings targets will trump more ecologically oriented regulatory proposals. Without confidence that species targets alone will conserve fish populations, most now invest their support in proposals that allow them to catch as many fish as possible before they and their family must leave the fishery forever, and/or will allow them to sell a permit for as high a sum as possible. They cynically negotiate for access to paper fish, suppressing their own observations of fish life histories, spatial patterns, and inter-species and habitat interactions. For example, the perceived illegitimacy of trip limits as conservation mechanisms due to discarding, especially if paired with higher ex-vessel prices for trip-limited species due to low landings, spur some boats to intentionally catch the maximum quantity allowed, instead of avoiding that species. Many fear that not catching the maximum limit could jeopardize future individual allocations because days-at-sea are based on catch histories, and individual quotas would likely be allocated similarly (audio recording and meeting summary, 29 November 2006, Portsmouth, New Hampshire, NEFMC scoping meeting for Multispecies Fishery Management Plan Amendment 16). In New Hampshire and Massachusetts, where larger cod spawning aggregations can be harvested closer to shore, some captains speak of catching "my" or "our" cod, meaning the boat's allotment or quota for the trip, to which they now apparently feel entitled. In the words of one high ranking NOAA Fisheries regional staff member, "Sometimes a trip limit becomes a goal instead of a constraint" (field audio recording and notes, 23 June 2010, Portland, Maine, NEFMC meeting).

Some lifelong opponents of ITQs who still hold useable groundfish permits now express support for ITQs as the last available option under the present catch share constraints, finding the administrative and political transaction costs of sectors to be too high, and anticipating that the largest firms will increasingly control sector administration and decision making. For example, one part-owner of a relatively large trawler spent some years fishing in Alaska and always detested ITQs after seeing excessive discards of small fish from boats wishing to fill their quota with larger and higher value fish. He privately supports basic tenets of area management and gear restrictions, but cannot endorse such proposals because he fears implementation overlaid on already existing regulations would put him out of business. Given the catch share constraints within which he must select a narrow range of regulatory options, he now expresses public support for ITQs as the most viable alternative, despite his continued ethical and ecological concerns (pers. comm. 2005, Portland, Maine; pers. comm., March 2010, Rockland, Maine). His father and business partner, however, still conveys that catch shares are "a travesty for New England and a disaster for Maine!" (written public comment on NOAA draft catch share policy, 2010).

\section{DISCUSSION}

\section{Divergent Policies}

In the case study presented here, even nascent sharebased fishery management mechanisms manifest ecosystem drawbacks in line with the literature summarized above on individual quota systems:

1. Fishing firms' consideration of habitat and inter-species variables, occupational ethics, and regulatory compliance are dampened by their limited faith in NOAA's information base and egalitarianism.

2. Fishing effort is consolidating away from smaller boat harbors and shows tendencies toward vertical integration and more mobile capital.

3. Shares are allocated to permit holders with large landings histories, eliminating diversified and flexible boats that reduced groundfishing effort when population depletions became apparent.

4. Shares do not internalize ecosystem services provided by habitat or inter-species relationships, or ecological goods represented by non-target species.

5. Aggregate catch targets based on the best available science have not been sufficient for widespread groundfish recovery. 
6. Sectors seem likely to decrease transparency and accountability by criteria other than catch share totals, with governance mechanisms being uncertain.

7. A sense of individual firm ownership or legal right to access, already developed around days-at-sea, is emerging around catch shares, entrenching political haggling over paper fish and discouraging thoughtful trade-offs among ecological goods and services.

8. Any rent-seeking, market distortions, information asymmetries, and path dependencies arising at the sector level will be difficult to discern or remedy because of reduced transparency and public scrutiny.

It would be unfair to judge sector management conclusively only a few months into implementation, but we can consider the experiences of fleet quotas, trip limits, and early indications of industry transformation under sectors. Under these mechanisms, little movement is visible toward ecosystem-based management goals gleaned from the existing literature, as summarized above:

1. The recovery of groundfish populations has been slow, and habitat and non-target species are not necessarily protected.

2. Total catch-focused management has not been very responsive to industry information, concerns, or conservation proposals and has been slow to reverse species population declines, suggesting limited capacity to respond strategically to changes in biophysical or social dimensions of the fished ecosystem.

3. Scientific understanding of social variables and the complexity of human-environment relationships has not been formally considered, even to the extent that conversations about differential gear impacts on habitat and species rarely take place.

4. Learning activities seem to be less focused on accommodating ecological uncertainties than on maximizing firms' fishing access, or anticipating the risk of legal action against NOAA.
5. Area closures and other spatially explicit considerations have thus far been trumped by catch shares.

6. Trade-offs are often driven by least-common denominators in the highly polarized Council process, rarely by broad and thoughtful public input.

\section{Implications for Resilience}

Conclusive evidence that catch shares do or do not benefit targeted fish populations is not provided by this nor other published studies, but this case does demonstrate that possible social-ecological drawbacks of catch shares merit further consideration, both from management and scientific perspectives. The question then becomes how to launch such efforts. As noted by scholars of coupled human-environment systems, resilience can be facilitated by scientific attention to (1) links between social and biophysical systems, (2) tradeoffs among ecosystem goods and services across scales and prospective ecosystem states, and (3) double-loop learning or adaptive organizational models that permit operational changes in response to new information (Argyris and Schön 1978, Berkes and Folke 1998, Walker et al. 2006, Leslie and Kinzig 2009).

In this vein, the Council brings considerable personal familiarity with human-environment systems, trade-offs, and flexible business organizational models to the table. It does not presently use scientific information derived from a human-environment perspective, prospective tradeoffs, or social learning, however. Rather, the Council relies primarily on target species population assessments, as required by FCMA, supplemented with limited information about habitat and social and economic domains. These information streams are rarely integrated or synthesized, discouraging rigorous consideration of relationships among biological, environmental, and social variables.

Social domains of social-ecological systems, like ecological domains, exhibit path dependencies. If resilient and ecosystem-based fishery management approaches are to gain traction, considerable human resources would be required for their thoughtful 
development. As discussed above, theoretical groundwork has been laid by natural and social scientists. Effective operationalization also requires administrative expertise, local knowledge, and more iterative and bidirectional exchanges between scientific and practical perspectives, however. Presently, New England fishermen, Council members, and perhaps fisheries managers, are administratively overextended coping with the brave new world of catch shares. In this reactive mode, they have no time to hone or advance arguments for innovative alternatives. Even groups formerly active on area management and gear restrictions, such as the Northwest Atlantic Marine Alliance and Penobscot East Resource Center, have had to refocus staff time to sort out the administrative requirements of, and political retrenchments around, sector quota allocations. Their financial, political, and human resource investment in catch shares may preclude opportunities to pursue more ecosystem-based management options indefinitely. Institutional memories are waning, as more recently hired staff do not have the same familiarity with previous areaand gear-focused proposals. Similarly, fishermen will likely become accustomed to sectors, as those uncomfortable with sectors drop out of them, and as firms favoring ITQs are likely to control some sectors, so that interest in non-sector and non-ITQ alternatives may diminish.

\section{Pending Spatial Planning Opportunities}

In light of the apparent disjuncture between catch shares and ecosystem-based fishery management, we can hope that a nascent federal framework for spatial marine planning included in the Obama Administration's national ocean policy might establish new venues for ecosystem-based thinking, especially if the Administration thoroughly operationalizes its stated intentions to incorporate natural and social sciences, and public input (Interagency Ocean Policy Task Force 2009). Placespecific collaboration across ecological, social science, fishing, and policy perspectives could stimulate considerable innovation in marine resource management, perhaps focused on empirically supported proposals for area-specific gear restrictions. Impending climate-driven biooceanographic changes, and increasing scholarly attention to how social-ecological variables interact and manifest differently across spatial scales, also encourage more adaptive and integrative approaches. Although most public conversations about marine spatial planning carefully sidestep jurisdictional questions about relationships between planning processes and the Fishery Management Councils, many planning advocates implicitly assume the Fishery Councils will ultimately answer to newly empowered and overriding decision bodies.

Because the Council system is widely perceived as being so dysfunctional, we might stake some hope on the possibility that the broader scope of marine governance could reinvigorate science-decision relationships around marine resource management in a way that is more integrative and synthetic. Given the inevitability of continued change in marine systems, including climate-related changes, the success of more comprehensive marine governance will require rigorous empirical understandings of social-ecological resilience and adaptive capacity. If decision-support systems and public participation processes are to be designed for this purpose, we can hope that our cautionary tale of Maine groundfish will be considered as an example of how ecosystem perspectives were made available to decision makers, but underused. As new decision networks arise from the national ocean policy and spatial planning initiative, we would be wise to build in the provision of information on human-environment links, ecosystem trade-offs, and institutional adaptiveness that is sorely missing in the groundfish case.

\section{CONCLUSION}

The groundfish case offers an opportunity to reflect on the potentially conflictual relationship between catch shares and ecosystem-based management. It cannot argue that a majority of New England fishermen explicitly endorse ecosystem-based management. Indeed, most have never heard the term, have no concrete idea about what it might mean, or express concern that it sounds like a conservationist crusade. Nonetheless, a majority of fishermen have long been inclined to think about fisheries management in ecological terms, and have vehemently opposed catch shares partly for this reason. Until the expansion of sectors as a pivotal catch share management mechanism in New England, an increasing number of fishermen in Maine were actively supporting specific proposals for ecosystem-oriented area management and gear restrictions. These proposals were repeatedly 
rejected by the New England Fishery Management Council. Sectors have instead become the primary Council focus, partly because of encouragement from NOAA, as both the agency and major ENGOs are promoting catch shares nationwide. With the discourse thus shifted, groups formerly active in support of area management and gear restrictions now find their resources absorbed in trying to make catch shares work, largely sidelining more ecologically cognizant proposals.

If this apparent policy divergence is not ameliorated, fishing interests will likely become more consolidated and vertically integrated under mobile capital, more politically entrenched, and more oblivious to lessons of the social-ecological past. From a short-term, purely monetary perspective, strong groundfish populations paired with continuing ecosystem decline under sector management might not be undesirable for some New England interests. Large mobile trawlers can work offshore waters and land product in southern New England ports, while small lobster boats remain inshore and provide local jobs, at least for the present. Loss of habitat, bio-economic diversity, local knowledge, and ecological stewardship are likely in this scenario, however, and are difficult to reverse. We may find ourselves with a fisheries management regime that is ostensibly successful in single-species terms, but not resilient to the longer term inevitability of environmental perturbations.

These policy challenges also play out in other North American fisheries, but often with even less public attention, perhaps due to their shorter post-colonial histories and less iconic cultural status. Cursory field data collection suggests that small-boat fishermen fear loss of fishery access and ecosystem impacts associated with industry consolidation under catch shares in places such as Alaska (field notes, 2 October 2006, Anchorage, Alaska, Alaska Fishing Communities conference; pers. comm., April 2007, Homer, Alaska), British Columbia (pers. comm., March 2004, Washington, D.C.; pers. comm., 15 April 2009, Columbia, North Carolina), California (pers. comm., January 2009, California), Florida (pers. comm., 2004, Washington, D.C.), North Carolina (pers. comm., 14 April, 2009, Duck, North Carolina, Mid-Atlantic Fishery Management Council meeting; pers. comm., 26 August 2009. Hatteras, North Carolina, Hatteras Connection meeting), New York (pers. comm., September 2005, Providence, Rhode Island, NEFMC meeting,), Nova Scotia (field notes, 1999, Rockland, Maine, Fishermen's Forum; field notes, 2003, Stonington, Maine, Turning the Tide meeting), and even the Ohio shores of Lake Erie (field observation, October, 2006, Port Clinton, Ohio). Similar observations are made by practitioners and scholars working overseas, especially those with an international development orientation (Berkes et al. 2001). In those settings, parallels with the experience of peasants and smallholders in the Green Revolution, including ecosystem impacts of consolidated land tenure, can be drawn more readily. In the United States, by contrast, although the implicit argument that catch shares discourage ecosystem resilience has long simmered within fishing communities, it has been less articulated in management and policy venues. Although many in the industry are certainly responsible for any number of other resource stewardship transgressions, this particular argument surely merits more vigorous scientific and public discussion. To miss such an opportunity is to erode public confidence in the ability of government to engage meaningfully with its diverse, if sometimes disorganized and belligerent, constituencies. If resource management is to be accountable and resilient, it must seek avenues for mutual learning among public, private, and non-governmental groups. As Upton Sinclair wrote, "[i]t is difficult to get a man to understand something, when his salary depends upon his not understanding it!" (Sinclair 1935).

Responses to this article can be read online at: http://www.ecologyandsociety.org/voll6/iss 1/art15/ responses/

\section{Acknowledgments:}

This research would not have been possible without the generosity and insight of innumerable informants, especially fishermen and their families, and public servants in federal and state offices. Many thanks for reviews of earlier drafts or for direct or indirect financial support are owed to two anonymous reviewers, Dianne Rocheleau, Bill L. Turner, Jim Wilson, Jim Acheson, Jody Emel, Tom H. Allen, Robin Alden, Enrique Reyes, Ellen Russell, MIT Sea Grant, Maine Sea Grant, Northeast Consortium, National Science Foundation, East Carolina University, Clark University, University 
of Maine, Darling Marine Center, Kendall Foundation, and Maine Department of Marine Resources.

\section{LITERATURE CITED}

123rd Maine State Legislature. 2007. Joint resolution memorializing the delegation of the 2008 New England Fishery Management Council to consider alternative actions to ensure a healthy sustainable groundfishery for New England, HP1688, LR 3657.

Acheson, J. M. 1988. Lobster gangs of Maine. New England University Press, Hanover, New Hampshire, USA.

Ames, E. P. 1997. Cod and haddock spawning grounds in the Gulf of Maine. Island Institute, Rockland, Maine, USA.

Ames, E. P. 2004. The stock structure of Atlantic cod in the Gulf of Maine. Fisheries 29:10-28.

Area Management Coalition. 2006. Local area management of groundfish: aframeworkfor moving New England forward. Saco, Maine, USA.

Argyris, C., and D. A. Schön. 1978. Organizational learning: a theory of action perspective. AddisonWesley, Reading, Massachusetts, USA.

Baranov, F. I. 1918. On the question of the biological basis of fisheries. Nauchnyi Issledovatelskii Iktiolohisheskii Institut Izvestiia 1:81-128.

Berkes, F. 2008. Commons in a multi-level world. International Journal of the Commons 2:1-6.

Berkes, F., and C. Folke, editors. 1998. Linking social and ecological systems : management practices and social mechanisms for building resilience Cambridge University Press, Cambridge, UK.

Berkes, F., R. Mahon, P. McConney, R. Pollnac, and R. Pomeroy. 2001. Managing small-scale fisheries. International Development Research Centre, Ottawa, Ontario, Canada.
Beverton, R. J. H., and S. J. Holt. 1957. On the dynamics of exploited fish populations. Fisheries Investigations Series 2:1-533.

Brewer, J. F. 2010. Polycentrism and flux in spatialized management: evidence from Maine's lobster (Homarus americanus) fishery. Bulletin of Marine Science 86:287-302.

Brodziak, J., S. X. Cadrin, C. M. Legault, and S. A. Murawski. 2008. Goals and strategies for rebuilding New England groundfish stocks. Fisheries Research 94:355-366.

Bromley, D. W. 2009. Abdicating responsibility: the deceits of fisheries policy. Fisheries 34:280 290.

Browman, H. I., and K. I. Stergiou. 2005. Politics and socio-economics of ecosystem-based management of marine resources. Marine Ecology Progress Series 300:241-296.

Catch Shares Working Group. 2008. Oceans of abundance: an action agenda for America's vital fishing future. Environmental Defense Fund, New York, New York, USA. [online] URL: http://www. edf.org/documents/8795 OceansOfAbundance.pdf

Christy, F. 1973. Fishermen's quotas: a tentative suggestion for domestic management. Law of the Sea Institute, University of Rhode Island, Kingston, Rhode Island, USA.

Copes, P. 1979. The economics of marine fisheries nanagement in the era of extended jurisdiction: the Canadian perspective. American Economic Review 69:256-260.

Copes, P. 1986. A critical review of the individual quota as a device in fisheries management. Land Economics 62:278-291.

Costello, C., S. D. Gaines, and J. Lynham. 2008. Can catch shares prevent fisheries collapse? Science 321:1678-1681.

Criddle, K. R., and S. Macinko. 2000. A requiem for the IFQ in US fisheries? Marine Policy 24:461469. 
Cury, P. M., and V. Christensen. 2005. Quantitative ecosystem indicators for fisheries management: introduction. ICES Journal of Marine Science 62:307-310.

Davis, A. 1996. Barbed wire and bandwagons: a comment on ITQ fisheries management. Reviews in Fish Biology and Fisheries 6:97-107.

Degnbol, P., H. Gislason, S. Hanna, S. Jentoft, J. Raakjær Nielsen, S. Sverdrup-Jensen, and D. Clyde Wilson. 2006. Painting the floor with a hammer: technical fixes in fisheries management. Marine Policy 30:534-543.

Dolšak, N., and E. Ostrom, editors. 2003. Commons in the new millenium: challenges and adaptations. MIT Press, Cambridge, Massachusetts, USA.

Ecological Society of America. 1998. Supplement: ecosystem management for sustainable marine fisheries. Ecological Applications 8:S139-S150.

Ecosystem Principles Advisory Panel. 1999. Ecosystem-based fishery management: a report to Congress. U.S. National Marine Fisheries Service, Washington, D.C., USA.

Environmental Defense Fund. 1994. EDF is advocating reforms to reduce overfishing, press release. New York, New York, USA. [online] URL: http://www.edf.org/article.cfm?contentID=1112.

Finley, C. 2009. The social construction of fishing, 1949. Ecology and Society 14(1):6. [online] URL: http://www.ecologyandsociety.org/vol14/iss1/art6

Gibbs, M. T. 2009. Individual transferable quotas and ecosystem-based fisheries management: it's all in the T. Fish and Fisheries 10:470-474.

Gibbs, M. T. 2010. Why ITQs on target species are inefficient at achieving ecosystem based fisheries management outcomes. Marine Policy 33:83-89.

Glaser, B., editor. 1994. More grounded theory: a reader. Sociology Press, Mill Valley, California, USA.

Glaser, B. G., and A. L. Strauss. 1967. The discovery of grounded theory: strategies for qualitative research. Aldine, Chicago, Illinois, USA.
Gordon, H. S. 1953. The economic theory of a common property resource: the fishery. Journal of Political Economy:124-142.

Griffith, D. 1999. Estuary's gift: an Atlantic coast cultural biography. University of Pennsylvania, University Park, Pennsylvania, USA.

Groundfish Task Force. 2004. Governor's taskforce on the Maine groundfish industry. Maine Department of Marine Resources, Augusta, Maine, USA.

Grumbine, R. E. 1994. What is ecosystem management? Conservation Biology 8:27-38.

Hanna, S. S. 2008. Institutions for managing resilient salmon (Oncorhynchus spp.) ecosystems: the role of incentives and transaction costs. Ecology and Society 13(2):35. [online] URL: http://www.ec ologyandsociety.org/vol13/iss2/art35/.

Haraway, D. 1988. Situated knowledges: the science question in feminism and the privilege of partial perspective. Feminist Studies 14:575-599.

Hennessey, T., and M. Healey. 2000. Luwig's ratchet and the collapse of New England groundfish stocks. Coastal Management 28:187-213.

Interagency Ocean Policy Task Force. 2009. Interim framework for effective coastal and marine spatial planning. White House Council on Environmental Quality, Washington, D.C., USA. [online] URL: http://www.whitehouse.gov/sites/default/files/ microsites/091209-Interim-CMSP-Framework-TaskForce.pdf.

Joint Oceans Commission Initiative. 2009. Changing ocean, changing world: ocean priorities for the Obama administration and Congress. Meridian Institute, Washington, D.C., USA. [online] URL: http://www.jointoceancommission.org/ resource-center/1-Reports/2009-04-07 JOCI Chan ging Oceans, Changing World.pdf.

Larkin, P. A. 1977. An epitaph for the concept of maximum sustainable yield. Transactions of the American Fisheries Society 106:1-11.

Lear, W. H. 1998. History of fisheries in the Northwest Atlantic: the 500-year perspective. Journal of Northwest Atlantic Fisheries Science 23:41-73. 
Leslie, H. M., and A. P. Kinzig. 2009. Resilience science. Pages 55-73 in K. McLeod and H. Leslie, editors. Ecosystem-based management for the oceans. Island Press, Washington, D.C., USA.

Libby, J. 2010. Opinion: double standards in the herring fishery don't work for groundfishermen. Portland Press Herald, Portland, Maine, USA.

Link, J. S. 2002. What does ecosystem-based fisheries management mean? Fisheries 27:18-21.

Lipfert, N. R., R. W. Judd, and R. R. Wescott. 1995. New industries in an age of adjustment, 1865-1930. Pages 240-447 in R. W. Judd, E. A. Churchhill, and $\mathrm{J}$. W. Eastman, editors. Maine: the pine tree state from prehistory to the present. University of Maine Press, Orono, Maine, USA.

Marine Fish Conservation Network. 2007. Comments to NOAA Office of Sustainable Fisheries on guidelines for implementing limited access privilege programs. Washington, D.C., USA. [online] URL: http://www.conservefish.org/storage/ marinefish3/documents/lappguidancemfen928071. pdf.

McCay, B. J. 2004. ITQs and community: an essay on environmental governance. Agricultural and Resource Economics Review 33:162-170.

McLeod, K. and H. Leslie, editors. 2009. Ecosystem-based management for the oceans. Island Press, Washington, D.C., USA.

McLeod, K. L., J. Lubchenco, S. R. Palumbi, and A. A. Rosenberg. 2005. Scientific consensus statement on marine ecosystem-based management. Communication Partnership for Science and the Sea. [online] URL: http://www.compassonline.org/ pdf files/EBM Consensus Statement v12.pdf.

Murawski, S. A. 2007. Ten myths concerning ecosystem approaches to marine resource management. Marine Policy 31:681--690.

Murawski, S. A., J.-J. Maguire, R. K. Mayo, and F. M. Serchuk. 1997. Groundfish stocks and the fishing industry. Pages 27-70 in J. Boreman, B. S. Nakashima, J. A. Wilson, and R. L. Kendall, editors. Northwest Atlantic groundfish: perspectives on a fishery collapse. American Fisheries Society, Bethesda, Maryland, USA.
National Oceanic and Atmospheric Administration (NOAA). 2001. Report of the 33rd northeast regional stock assessment workshop (33rd SAW): stock assessment review committee (SARC) consensus summary of assessments. Northeast Fisheries Science Center, Woods Hole, Massachusetts, USA. [online] URL: http://www.nefsc.noaa.gov/nefsc/ publications/crd/crd0118/0118.pdf.

NOAA. 2004. Brief history of the groundfishing industry of New England. Northeast Fisheries Science Center, Woods Hole, Massachusetts, USA. [online] URL: http://www.nefsc.noaa.gov/history/s tories/groundfish/grndfsh1.html.

NOAA. 2008. Assessment of 19 northeast groundfish stocks through 2007: report of the 3rd groundfish assessment review meeting, 4-8 August 2008. Northeast Fisheries Science Center, Woods Hole, Massachusetts, USA. [online] URL: http://w ww.nefsc.noaa.gov/nefsc/publications/crd/crd0815/

NOAA. 2009. Draft NOAA catch share policy. NOAA, Washington, D.C., USA.

National Research Council. 1999. Sharing the fish: toward a national policy on individual fishing quotas. National Academies Press, Washington, D. C., USA. [online] URL: http://www.nap.edu/catalog. php?record $\mathrm{id}=6335 \#$ toc.

National Research Council. 2002. Drama of the commons. National Academies Press, Washington, D.C., USA. [online] URL: http://www.nap.edu/cata log.php?record $\mathrm{id}=10287$ \#toc.

National Research Council. 2006. Dynamic changes in marine ecosystems: fishing, food webs, and future options National Academies Press, Washington, D.C., USA. [online] URL: http://www .nap.edu/catalog.php?record id=11608\#toc.

New England Fishery Management Council and National Marine Fisheries Service. 2003. Final amendment 13 to the northeast multispecies fishery management plan including a final supplemental environmental impact statement and an initial regulatory flexibility analysis. Newburyport, Massachusetts, USA. [online] URL: http://www.ne fmc.org/nemulti/index.html. 
Northwest Atlantic Marine Alliance. 2002. Gulf of Maine inshore fisheries conservation and stewardship plan of 2002. Saco, Maine, USA. [online] URL: http://www.nefmc.org/nemulti/planamen/ Appendix XIII GOMStewardshipPlan.pdf.

Office of the President. 2004. U.S. ocean action plan: the Bush Administration's response to the $U$. $S$. Commission on Ocean Policy. Executive Office of the President of the United States, Washington, D.C., USA.

O'Leary, W. M. 1996. Maine sea fisheries: the rise and fall of a native industry, 1830-1890. Northeastern University Press, Boston, Massachusetts, USA.

Penobscot East Resource Center. 2007. Economic loss to Maine from groundfish collapse. Stonington, Maine, USA.

Pew Environment Group. 2009. Design matters: making catch shares work. Pew Charitable Trusts, Washington, D.C., USA, [online] URL: http://www .pewtrusts.org/uploadedFiles/wwwpewtrustsorg/Reports/ Protecting ocean life/CatchShare.pdf? $\mathrm{n}=5322$.

Pew Oceans Commission. 2003. America's living oceans: charting a course for sea change. Pew Charitable Trusts, Philadelphia, Pennsylvania, USA. [online] URL: http://www.pewtrusts.org/uplo adedFiles/wwwpewtrustsorg/Reports/Protecting oc ean life/env pew oceans final report.pdf.

Pikitch, E. K., C. Santora, E. A. Babcock, A. Bakun, R. Bonfil, D. O. Conover, P. Dayton, P. Doukakis, D. Fluharty, B. Heneman, E. D. Houde, J. Link, P. A. Livingston, M. Mangel, M. K. McAllister, J. Pope, and K. J. Sainsbury. 2004. Ecosystem-based fishery management. Science 305:346-347.

Pinkerton, E., and D. N. Edwards. 2009. The elephant in the room: the hidden costs of leasing individual transferable fishing quotas. Marine Policy 33:707-713.

Pinto da Silva, P., and A. Kitts. 2006. Collaborative fisheries management in the northeast US: emerging initiatives and future directions. Marine Policy 30:832-841.

Ramirez-Sanchez, S., and E. Pinkerton. 2009. The impact of resource scarcity on bonding and bridging social capital: the case of fishers' information- sharing networks in Loreto, BCS, Mexico Ecology and Society 14(1): 22. [online] URL: http://www.e cologyandsociety.org/articles/2841.html.

Rettig, B. R., and J. J. C. Ginter, editors. 1978. Limited entry as a fishery management tool. University of Washington Sea Grant, Seattle, Washington, USA.

Ricker, W. E. 1948. Methods of estimating vital statistics of fish populations. Indiana University, Bloomington, Indiana, USA.

Rieser, A. 1997. Property rights and ecosystem management in U.S. fisheries: contracting for the commons? Ecology Law Quarterly 24:813-832.

Rosenberg, A. A. 2009. Changing U.S. ocean policy can set a new direction for marine resource management. Ecology and Society 14. [online] htt p://www.ecologyandsociety.org/vol14/iss2/art6/.

Ruzzante, D. E., C. T. Taggart, R. W. Doyle, and D. Cook. 2001. Stability in the historical pattern of genetic structure of Newfoundland cod (Gadus morhua) despite the catastrophic decline in population size from 1964 to 1994. Conservation Genetics 2:257-269.

Schaefer, M. B. 1954. Some aspects of the dynamics of populations important to the management of the commercial marine fisheries. Bulletin of the InterAmerican Tropical Tuna Commission 1:27-56.

Scheiber, H. N. 1997. From science to law to politics: an historical view of the ecosystem idea and its effect on resource management. Ecology Law Quarterly 24:631.

Scott, A. 1955. The fishery: the objectives of sole ownership. Journal of Political Economy 63:116124.

Sen, A. 2009. The idea of justice. Belknap Press, Cambridge, Massachusetts, USA.

Sinclair, U. 1935. I, candidate for governor: and how I got licked. Farrar and Rinehart, New York, New York, USA.

Strauss, A., and J. Corbin. 1990. Basics of qualitative research: grounded theory procedures and techniques. Sage, Thousand Oaks, California, USA. 
Tallis, H., P. S. Levin, M. Ruckelshaus, S. E. Lester, K. L. McLeod, D. L. Fluharty, and B. S. Halpern. 2010. The many faces of ecosystem-based management: making the process work today in real places. Marine Policy 34:340-348.

Turris, B. R. 2010. A rejoinder to E. Pinkerton et al., the elephant in the room: the hidden costs of leasing individual transferable fishing quotas. Marine Policy 34:431-436.

United Nations Food and Agriculture Organization. 2002. Report of the expert consultation on ecosystem-based fisheries management, Reykjavik, Iceland, 16-19 September 2002. United Nations Food and Agriculture Organization, Rome, Italy. [online] URL: http://www.fao.org/docrep/005/y4491t/ y4491t00.htm.

U.S. Commission on Ocean Policy. 2004. An ocean blueprint for the 21 st century. Washington, D.C., USA. [online] URL: http://oceancommission.gov/d ocuments/full color rpt/welcome.html\#full.

Varjopuro, R., T. Gray, J. Hatchard, F. Rauschmayer, and H. Wittmer. 2008. Introduction: interaction between environment and fisheries - the role of stakeholder participation. Marine Policy 32:147-157.

Vickers, D. 1994. Farmers and fishermen: two centuries of work in Essex County, Massachusetts, 1630-1850. Institute of Early American History and Culture, Williamsburg, Virginia, USA.

Walker, B. H., L. H. Gunderson, A. P. Kinzig, C. Folke, S. R. Carpenter, and L. Schultz. 2006. A handful of heuristics and some propositions for understanding resilience in social-ecological systems. Ecology and Society 11(1): 13. [online] URL: http://www.ecologyandsociety.org/vol11/iss1/ art13/.

Walters, C. J., V. Christensen, S. J. Martell, and J. F. Kitchell. 2005. Possible ecosystem impacts of applying MSY policies from single-species assessment. ICES Journal of Marine Science 62:558-568.

Wilson, J. A. 1982. The economical management of multispecies fisheries. Land Economics 58:417434.
Wilson, J. A. 1990. Fishing for knowledge. Land Economics 66:12-29.

Wilson, J. A., J. Acheson, and P. Kleban. 1996. Chaos and parametric management. Marine Policy 20:429-438.

Wilson, J. A., B. Low, R. Costanza, and E. Ostrom. 1999. Scale misperceptions and the spatial dynamics of a social-ecological system. Ecological Economics 31:243-257. 


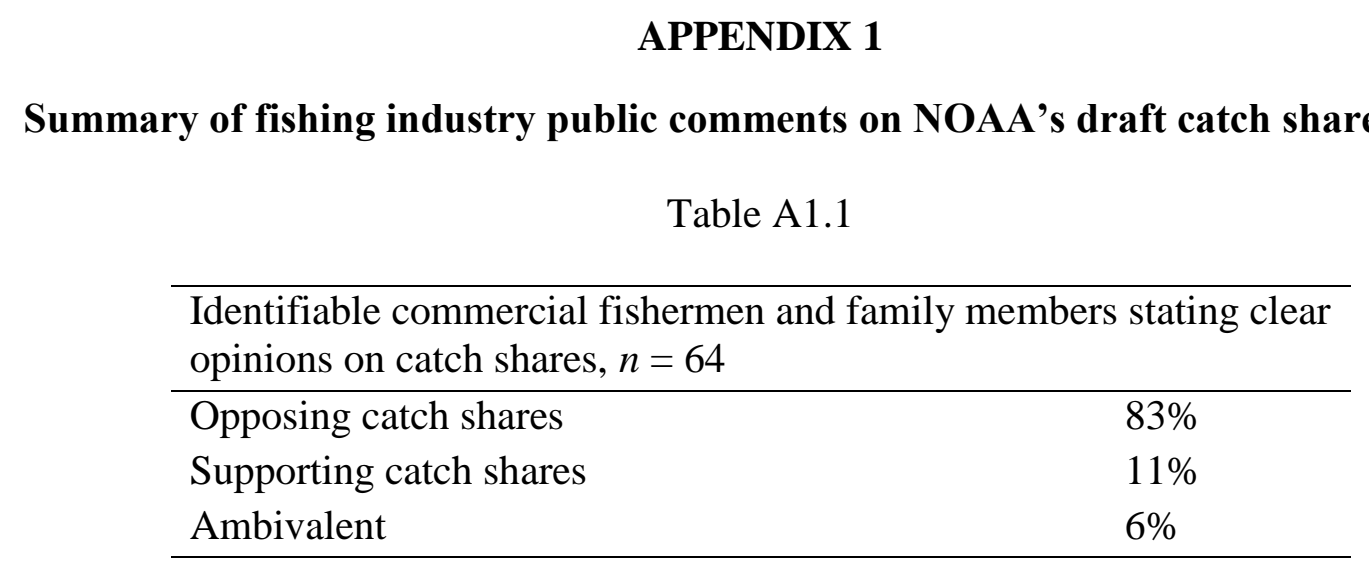

Table A1.2

Identifiable recreational fishermen stating clear opinions on catch shares, $n=83$

Opposing catch shares $90 \%$

Supporting catch shares $5 \%$

Opposing recreational but supporting commercial catch shares $3 \%$

Ambivalent

$1 \%$




\section{APPENDIX 2}

\section{Partial data summary}

Table A2.1

Partial summary of extended in-person interviewees by location

(Excludes larger number of shorter, informal conversations.)

\begin{tabular}{ll}
\hline \hline Principal base of operations, $n=166$ & Number of interviewees \\
\hline Maine & 140 \\
New Hampshire & 1 \\
Massachusetts & 8 \\
Rhode Island & 2 \\
North Carolina & 5 \\
Alaska & 5 \\
Elsewhere & 5 \\
\hline
\end{tabular}

Table A2.2

Partial summary of extended in-person interviewees by relationship to fishing industry (Some interviewees fit more than one category. Excludes larger number of shorter, informal conversations. Excludes normal professional conversations with academic colleagues.)

\begin{tabular}{ll}
\hline \hline Relationship to industry, $n=166$ & Number of interviewees \\
\hline Fisherman & 122 \\
Fishing family member, not primarily fisherman & 8 \\
Fishing dependent business, not primarily fishing & 12 \\
Non-profit organization & 13 \\
Government & 10 \\
Management advisory group & 25 \\
Scientist & 6 \\
\hline
\end{tabular}

Table A2.3

Partial list of public meetings attended (Excludes private meetings, academic conferences, and site visits.)

\begin{tabular}{llll}
\hline \hline Year & Location & Purpose & Estimated time attended \\
\hline$\sim 1991$ & Portland, ME & NEFMC scoping meeting & 2 hours \\
$\sim 1991$ & Portland, ME & NEFMC hearing & 2 hours \\
1999 & Machias, ME & Maine DMR lobster zone meeting & 2 hours \\
1999 & Bar Harbor, ME & Maine DMR lobster zone meeting & 2 hours \\
1999 & Stonington, ME & Maine DMR lobster zone meeting & 2 hours
\end{tabular}




\begin{tabular}{|c|c|c|c|}
\hline 1999 & Kennebunk, ME & Maine DMR lobster zone meeting & 2 hours \\
\hline 1999 & York, ME & Maine DMR lobster zone meeting & 2 hours \\
\hline 1999 & Rockland, ME & Fishermen's Forum & 3.5 days \\
\hline 1999 & eastern ME & Maine DMR urchin zone meeting & 3 hours \\
\hline 2000 & Rockland, ME & Fishermen's Forum & 5 days \\
\hline 2001 & Rockland, ME & Fishermen's Forum & .5 days \\
\hline 2001 & Portsmouth, NH & $\begin{array}{l}\text { Northeast Consortium fisheries } \\
\text { collaborative research conference }\end{array}$ & 1 day \\
\hline 2001 & Rockland, ME & $\begin{array}{l}\text { Atlantic States Marine Fisheries } \\
\text { Commission meeting }\end{array}$ & 1 day \\
\hline 2002 & Rockland, ME & Fishermen's Forum & 2 days \\
\hline 2003 & Portland, ME & NEFMC hearing & 4 hours \\
\hline 2003 & Portland, ME & NEFMC scoping meeting & 2 hours \\
\hline 2003 & Rockland, ME & Fishermen's Forum & 3.5 days \\
\hline 2003 & Stonington, ME & Turning the Tide workshop & 1 day \\
\hline$\sim 2003$ & Damariscotta, ME & Maine DMR scoping meeting & 1 hour \\
\hline$\sim 2003$ & Machias, ME & Maine DMR regulatory hearing & 3 hours \\
\hline 2003 & Wiscasset, ME & Maine DMR regulatory hearing & 3 hours \\
\hline 2004 & Rockland, ME & Fishermen's Forum & 2 days \\
\hline 2004 & Washington, DC & $\begin{array}{l}\text { Congressional FCMA reauthorization } \\
\text { hearing }\end{array}$ & 2 hours \\
\hline 2004 & Washington, DC & Congressional House Oceans Week & 1 day \\
\hline 2004 & Washington, DC & US and Pew Ocean Commissions briefing & 2 hours \\
\hline 2004 & Bristol, RI & Marine Law Symposium & 2 days \\
\hline 2005 & Providence, RI & NEFMC meeting & 3 days \\
\hline 2005 & Portland, ME & NEFMC meeting & 2 days \\
\hline 2005 & Portland, ME & NEFMC committee meeting & 1 day \\
\hline 2005 & Revere, MA & NEFMC committee meeting & 1 day \\
\hline 2005 & Rockland, ME & Fishermen's Forum & 2 days \\
\hline 2005 & Rockland, ME & Fleet Visioning workshop & 3 hours \\
\hline 2005 & North Shore, MA & Fleet Visioning workshop & 1 day \\
\hline 2005 & Washington, DC & Managing our Nation's Fisheries conference & 2 days \\
\hline 2006 & Portland, ME & NEFMC meeting & 1 day \\
\hline 2006 & Anchorage, AK & $\begin{array}{l}\text { Alaska Sea Grant Fishing Communities } \\
\text { conference }\end{array}$ & 1 day \\
\hline 2009 & Duck, NC & $\begin{array}{l}\text { Mid-Atlantic Fishery Management } \\
\text { Council meeting }\end{array}$ & 1 day \\
\hline 2009 & Hatteras, NC & Hatteras Connection meeting & 2 hours \\
\hline 2009 & Columbia, NC & Environmental Defense workshop & 2 hours \\
\hline 2010 & Rockland, ME & Fishermen's Forum & 3.5 days \\
\hline 2010 & Stoning, ME & Community Fisheries Action Roundtable & 4 days \\
\hline 2010 & Portland, ME & NEFMC meeting & .5 day \\
\hline
\end{tabular}

